\title{
The relevance of biomarkers 1 year after heart transplantation: is there increased predictive value of high sensitive troponin?
}

\section{Dora Fabijanović*, Ivo Planinc, \\ Jana Ljubas Maček, Boško Skorić, Željko Baričević, Hrvoje Jurin, Jure Samardžić, Hrvoje Gašparović, Maja Čikeš, \\ Davor Miličić}

University of Zagreb School of Medicine, University Hospital Centre Zagreb, Zagreb, Croatia

\begin{abstract}
KEYWORDS: heart transplantation, high sensitive troponin, brain natriuretic peptide. CITATION: Cardiol Croat. 2015;10(9-10):207. | DOI: http://dx.doi.org/10.15836/ccar.2015.207

*ADDRESS FOR CORRESPONDENCE: Dora Fabijanović, Klinički bolnički centar Zagreb, Kišpatićeva 12, HR-10000 Zagreb, Croatia. / Phone: +385-98-9387273 / E-mail: dora.fabijanovic@gmail.com

ORCID: Dora Fabijanović, http://orcid.org/0000-0003-2633-3439 • Ivo Planinc, http://orcid.org/0000-0003-0561-6704 Jana Ljubas Maček, http://orcid.org/0000-0001-7171-2206 • Boško Skorić, http://orcid.org/0000-0001-5979-2346 Željko Baričević, http://orcid.org/0000-0002-5420-2324 • Hrvoje Jurin, http://orcid.org/0000-0002-2599-553X Jure Samardžić, http://orcid.org/0000-0002-9346-6402 • Hrvoje Gašparović, http://orcid.org/0000-0002-2492-3702 Maja Čikeš, http://orcid.org/0000-0002-4772-5549 • Davor Miličić, http://orcid.org/0000-0001-9101-1570
\end{abstract}

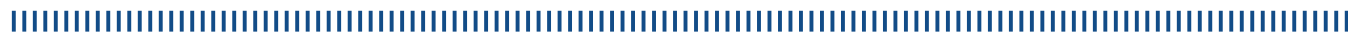

GOAL: The clinical value of cardiac biomarkers (such as brain natriuretic peptide (BNP) or troponin T) in heart transplant (HTx) recipients is not completely defined. Despite multiple published studies on the association between cardiac biomarkers and survival or acute allograft rejection, there is insufficient evidence to recommend them in everyday clinical practice. ${ }^{1,2}$ We sought to explore survival of patients after HTx in relation to NTpro-BNP and high sensitive TnT (hs-TnT) values throughout the 1st

Survival Functions

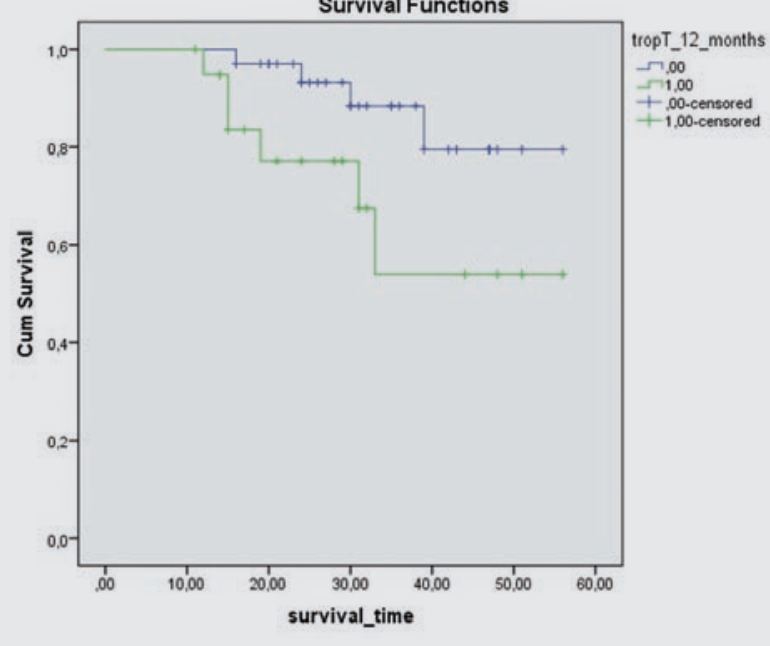

FIGURE 1. Cumulative survival based on hs-TnT levels 12 months post-Htx.

RECEIVED:

September 14, 2015

ACCEPTED:

September 17, 2015

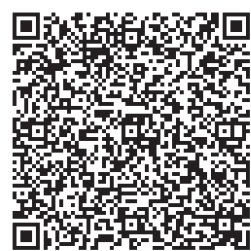
higher risk for worse outcomes.
post-HTx year in our center.

PATIENTS AND METHODS: In this retrospective observational study we included 74 consecutive HTx recipients (53 male, median follow-up 24 months) in whom we obtained NTpro-BNP (pg/mL) and hs-TnT (pg/L) values at 1, 6 and 12 months after HTx. For each time point, we used the median of measurements as a cut-off value for further analysis. Survival rates were analysed by the Kaplan-Meier method (log rank test), followed by the univariate Cox hazard regression analysis.

RESULTS: Cut-off median values for respective measurements at specific time points were as follows: NTpro-BNP 1967.5, 418.7 and $366.8 \mathrm{pg} / \mathrm{mL}$; hs-TnT 90, 18.5 and $16 \mathrm{pg} / \mathrm{L}$ at 1,6 and 12 months after HTx, respectively. The patients with lower hs-TnT values at 12 -months after HTx had significantly better survival rates $(p=0.048)$ (Figure 1), with a HR of 1.014 (95\% CI 1.003-1.024 $\mathrm{p}=0.01)$. Although NTpro-BNP and hs-TnT values at the earlier time points showed a trend towards better survival in patients with lower biomarker values, statistical significance was not observed.

CONCLUSION: The results of our study suggest the importance of biomarker measurements (particularly hs-TnT), even in the later post-transplant period. Larger study groups might enforce its role in detecting individuals at

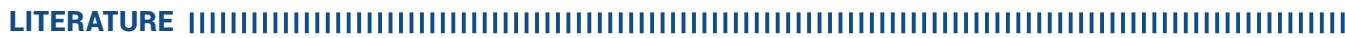

1. Erbel C, Taskin R, Doesch A, Dengler TJ, Wangler S, Akhavanpoor M, et al. High-sensitive Troponin T measurements early after heart transplantation predict short- and long-term survival. Transpl Int. 2013;26(3):267-72. DOI: http://dx.doi.org/10.1111/tri.12024

2. Battes LC, Caliskan K, Rizopoulos D, Constantinescu AA, Robertus JL, Akkerhuis M, et al. Repeated measurements of NT-pro-B-type natriuretic peptide, troponin $\mathrm{T}$ or $\mathrm{C}-$ reactive protein do not predict future allograft rejection in heart transplant recipients. Transplantation. 2015;99(3):580-5. DOI: http://dx.doi.org/10.1097/TP.0000000000000378 